\title{
Analysis of the Coloring and Antibacterial Effects of Natural Dye: Pomegranate Peel
}

\author{
Aicha Bouaziz ${ }^{1,2,+}$, Dorra Dridi ${ }^{3,+}$, Sondes Gargoubi ${ }^{4, *}$, Souad Chelbi ${ }^{2}$, Chedly Boudokhane ${ }^{5}$, \\ Abderraouf Kenani ${ }^{6}$ and Sonia Aroui ${ }^{6}$
}

check for updates

Citation: Bouaziz, A.; Dridi, D.; Gargoubi, S.; Chelbi, S.; Boudokhane, C.; Kenani, A.; Aroui, S. Analysis of the Coloring and Antibacterial Effects of Natural Dye: Pomegranate Peel. Coatings 2021, 11, 1277. https:// doi.org/10.3390/coatings11111277

Academic Editor: Philippe Evon

Received: 19 August 2021

Accepted: 19 September 2021

Published: 21 October 2021

Publisher's Note: MDPI stays neutral with regard to jurisdictional claims in published maps and institutional affiliations.

Copyright: (c) 2021 by the authors. Licensee MDPI, Basel, Switzerland. This article is an open access article distributed under the terms and conditions of the Creative Commons Attribution (CC BY) license (https:/ / creativecommons.org/licenses/by/ $4.0 /)$.
1 Bio-Resources, Integrative Biology \& Valorization (BIOLIVAL, LR14ES06), Higher Institute of Biotechnology of Monastir, University of Monastir, Monastir 5000, Tunisia; bouaziz.aicha@gmail.com

2 Higher School of Health Sciences and Techniques of Sousse, University of Sousse, Sousse 4054, Tunisia; souad_chelbi@yahoo.fr

3 Unit of Analysis and Process Applied to the Environment (UR17ES32) Issat Mahdia, University of Monastir Monastir 5000, Tunisia; dorra.dridi.jeddi@gmail.com

4 Textile Engineering Laboratory_LGTex, University of Monastir, Monastir 5000, Tunisia

5 Research Unity of Applied Chemistry and Environment, Faculty of Science of Monastir, University of Monastir, Monastir 5000, Tunisia; chimi.tex@planet.tn

6 Research Laboratory "Environment, Inflammation, Signaling and Pathologies" (LR18ES40), Faculty of Medicine of Monastir, University of Monastir, Monastir 5019, Tunisia; raouf.kenani@fmm.rnu.tn (A.K.); sonia_aroui2002@yahoo.fr (S.A.)

* Correspondence: gargoubisondes@yahoo.fr

+ A. Bouaziz and D. Dridi contributed equally to this work as first authors.

\begin{abstract}
This work aims to conduct an eco-friendly textile finishing process by applying agricultural by-products as a dye for the finishing of polyamide fabrics. A natural dye was obtained from pomegranate peel extract. Polyamide fabrics were dyed at different conditions, and four mordanting agents were tested. The finished fabrics were analyzed in terms of CIE $\mathrm{L}, \mathrm{a}, \mathrm{b}$ and color yield (K/S) values, as well as washing fastness, rubbing fastness, light fastness and antibacterial activity. Results show that pomegranate peel extract could dye polyamide fabrics. The rubbing and washing fastness of the finished samples was good. The light fastness was fair, and its antibacterial efficiency against the tested bacteria was good.
\end{abstract}

Keywords: polyamide; pomegranate peel; natural dye; mordant; fastness; antibacterial

\section{Introduction}

Vegetables and fruits play a significant part in our daily life. The request for such imperative commodities has expanded with the increase in world population [1]. Mass consumption has led to a higher generation of by-products and has created a disposal problem [2].

Vegetable and fruit by-products could be an important and profitable source of natural compounds [3]. Numerous research has shown that the generated compounds are great sources of phenolics, natural acids, sugar, colors and minerals. Some of these natural compounds exhibit bioactive functions such as antibacterial, antitumor, antifungal, antiviral, antimutagenic and cardioprotective [4,5].

Although some of the generated by-products can be considered unavoidable, others can be utilized in different domains, including pharmaceutical, food, textile and cosmetic industries [6-8]. The valorization of by-products may be a promising way to establish sustainable development and reduce environmental problems [9]. Waste management procedures must be installed with the increasing valorization of by-products and industries must develop new ways of recycling wastes.

In line with green trends towards sustainability, textile researchers have found great potential in using plant extracts as natural dyes [10]. Much research has focused on 
studying the chemical composition and functional properties of these natural dyes [11]. In this context, pomegranate peel extracts were extensively used as a source of yellow dye [11].

The pomegranate is one of the oldest cultivated fruits in the world [12]. This fruit is broadly spread throughout numerous nations, and it is well adapted to dry zones and the Mediterranean climate [13]. In addition, pomegranate peel accounts for nearly half of the entire weight of the fruit [14].

A review of the literature shows that there have been relatively few studies investigating the dyeing of polyamide fibers with pomegranate peel [15] or the bio-functional activities of the dyed substrates. In addition, there has been far less research on dyeing using mordant concentration, which does not exceed the limits specified by environmental and health standards. Therefore, the target of the present work is to demonstrate the feasibility of applying pomegranate peel extract as a natural functional dye for polyamide substrates. This research evaluated the effects of four mordants on color yield (K/S): color fastness, rubbing, light and washing. To the best of our knowledge, this is an original study on polyamide dyeing, using pomegranate peel extract to assess ecofriendly mordant dyeing and antibacterial finishing.

\section{Materials and Methods}

\subsection{Materials}

Pomegranate fruits were purchased from local shops. The peels were collected, dried in the sun, and then powdered. Commercially available polyamides (purchased from local shops) were used, and for the entire set of studies, analytical grade chemicals were employed. The used chemicals are: Folin-Ciocalteu (LOBA Chemie, Mumbai, India), Gallic acid solution, sodium carbonate $(75 \%)$, sodium nitrate $\mathrm{NaNO}_{2}(5 \%, w / v)$, aluminum trichloride $\mathrm{AlCl}_{3}(10 \%, w / v)$ Catechin (kindly provided by FSM university), $\mathrm{C}_{3} \mathrm{H}_{6} \mathrm{O}_{3}$, Sodium hydroxide solution (1M NaOH) (Kindly provided by Chimitex company), Phosphate buffer solution (PBS) (Kindly provided by local hospital).

\subsection{Aqueous Extraction}

A mass of $20 \mathrm{~g}$ of the powdered pomegranate peels was taken in a $250 \mathrm{~mL}$ flask and covered with $50 \mathrm{~mL}$ of pure water in order to keep the plant material fully immersed in water. The flask was then kept at $90^{\circ} \mathrm{C}$ for $120 \mathrm{~min}$. Thus, natural dye from pomegranate peels was obtained by the aqueous extraction technique. After the complete extraction of dye, the mixture was filtered, and residual entities were extracted from the liquor. A reflux system was used during extraction to avoid solvent evaporation.

\subsection{Content of Total Phenols}

The Folin-Ciocalteu reagent was used to evaluate the total phenolic content of the aqueous extract. Quantification of total phenols is made by comparing the absorbance observed with that obtained by a Gallic acid solution with a known concentration [15].

A mixture of $0.4 \mathrm{~mL}$ of the pomegranate peel extract and $10 \mathrm{~mL}$ of diluted FolinCiocalteu reagent was subjected to stirring and then kept at ambient temperature for $5 \mathrm{~min}$. After stirring, $8 \mathrm{~mL}$ of an aqueous solution of sodium carbonate (75\%) was added. After $1 \mathrm{~h}$, the absorbances were determined at the wavelength of $765 \mathrm{~nm}$ using a spectrophotometer (Specord 210 plus, Analytik Jena AG, Jena, Germany). The concentration of phenolic compounds was determined using a calibration curve of Gallic acid and reported in $\mathrm{mg}$ Gallic acid equivalent (GAE)/g of extract.

\subsection{Total Flavonoids Content}

Flavonoids were quantified in accordance with the method defined by Zhishen et al. using aluminum trichloride and sodium hydroxide [16]. Aluminum trichloride forms a yellow complex with flavonoids, and sodium hydroxide forms a pink complex that absorbs in the visible range of $510 \mathrm{~nm}$ [15]. 
A volume of $1 \mathrm{~mL}$ of pomegranate peel extract was added to $4 \mathrm{~mL}$ of pure water and $0.3 \mathrm{~mL}$ of sodium nitrate $\mathrm{NaNO}_{2}(5 \%, w / v)$. The system was mixed and kept in the dark at room temperature for $5 \mathrm{~min}$, then $0.3 \mathrm{~mL}$ of aluminum trichloride $\mathrm{AlCl}_{3}$ $(10 \%, w / v)$ was added. After $10 \mathrm{~min}$ in the dark, $2 \mathrm{~mL}$ of sodium hydroxide solution $(1 \mathrm{M} \mathrm{NaOH})$ was added. The mixture was stirred, and the absorbance was determined using a spectrophotometer (Specord 210 plus, Analytik Jena AG, Jena, Germany) at the wavelength $510 \mathrm{~nm}$. Flavonoids were quantified using a calibration curve performed using Catechin and expressed in milligrams $(\mathrm{mg})$ equivalent to Catechin per gram of extract ( $\mathrm{mg} \mathrm{CE} / \mathrm{g})$.

\subsection{Visible Absorption Spectra}

The visible absorbance spectra of the pomegranate peel aqueous extract were recorded using a visible spectrophotometer (DR/3900, Hach, Colorado, CO, USA). Measurements were performed by wavelength scan over the visible range of 320 to $800 \mathrm{~nm}$.

\subsection{Dyeing Process}

To dye the polyamide fabrics with pomegranate peel extract, the exhaust process was applied using a bath ratio of 40:1. The $\mathrm{pH}$ was adjusted to 3 for all dye baths. During dyeing, the temperature was raised from $25^{\circ} \mathrm{C}$ to the dyeing temperature $\left(40{ }^{\circ} \mathrm{C}, 60^{\circ} \mathrm{C}\right.$, $80^{\circ} \mathrm{C}$ and $100^{\circ} \mathrm{C}$ ) at a rate of $2{ }^{\circ} \mathrm{C} / \mathrm{min}$. The samples were treated for $45 \mathrm{~min}$. After dyeing, polyamide fabrics were subjected to water rinsing cycles (1 $\mathrm{min}$ at ambient temperature for each cycle). Finally, the dyed samples were air-dried.

To improve dyeability, a mordanting technique was applied. An amount of $3 \%$ of mordant was used during dyeing. The released metal ions were quantified using inductively coupled plasma optical emission spectrometry (ICP OES, Perkin Elmer, Norwalk, CT, USA). An artificial acidic sweat solution made according to the ISO 3160/2 standard was used to extract metal ions from polyamide fabrics. A dilution of $20 \mathrm{gL}^{-1} \mathrm{NaCl}, 17.5 \mathrm{gL}^{-1} \mathrm{NH}_{4} \mathrm{Cl}$, $5 \mathrm{~g} \mathrm{~L}^{-1} \mathrm{CH}_{3} \mathrm{COOH}$, and $15 \mathrm{~g} \mathrm{~L}^{-1} \mathrm{C}_{3} \mathrm{H}_{6} \mathrm{O}_{3}$ was used to prepare the acidic sweat solution. To adjust the $\mathrm{pH}$ value at 4.7 , sodium hydroxide $\left(0.1 \mathrm{~mol} \mathrm{~L}^{-1}\right)$ was used [17].

A mass of $1.5 \mathrm{~g}$ of each polyamide fabric was vortexed with $25 \mathrm{~mL}$ of artificial sweat solution for $2 \mathrm{~h}$ at $40{ }^{\circ} \mathrm{C}$. ICP OES was used to examine the solutions after they had been filtered.

The concentrations of removed metal ions from dyed fabrics were found not to exceed the limits specified by the Öko Tex standard [18].

\subsection{Colorimetric Data}

A spectrophotometer (Datacolor $650^{\circledR}$, Lawrenceville, NJ, USA) was used to record light reflectance measurements under illuminant D65 and a $10^{\circ}$ standard observer. These measurements allow for the analysis of colorimetric data. The International Commission on Illumination's CIELab color coordinates ( $\mathrm{L}$, $\mathrm{a}$, and $\mathrm{b}$ ) were recorded. The letter $\mathrm{L}$ stands for lightness-darkness values, whereas the letter A stands for red-green share and ranges from negative (green) to positive (red).

The yellow-blue share is represented by $b$ values, which range from negative (blue) to positive (yellow). The standard color strength value $(\mathrm{K} / \mathrm{S})$ was calculated based on the Kubelka-Munk equation:

$$
\left(1-\mathrm{R}_{\lambda \max }\right)^{2} / 2 \mathrm{R}_{\lambda \max }=\mathrm{K} / \mathrm{S}
$$

where $\mathrm{S}$ is the scattering coefficient, $\mathrm{R}$ is the reflectance of the dyed fabric and $\mathrm{K}$ is the absorption coefficient.

\subsection{Fastness Evaluation}

The ISO standard methods were applied to evaluate the fastness properties of dyed fabrics. The considered standards were as follows: ISO 105-C06 for washing fastness, ISO 105-X12 for dry and wet rubbing fastness and ISO 105-B02 for light fastness. 


\subsection{Antibacterial Testing}

Escherichia coli (ATCC 8739) and Staphylococcus aureus (ATCC 6538) were used to evaluate the antibacterial activity of polyamide fabrics according to ASTM E2149. In this method, the polyamide samples $(1 \mathrm{~g})$ were placed in a flask containing a diluted suspension of bacteria using a phosphate buffer solution (PBS) to obtain a concentration of $3 \times 10^{5} \mathrm{UFC} / \mathrm{mL}$.

Treated and control samples were placed in laboratory flasks and shaken with $50 \mathrm{~mL}$ of the bacteria suspension for $1 \mathrm{~h}$ at $200 \mathrm{rpm}$. Then, $0.1 \mathrm{~mL}$ of prepared suspension was taken from each flask and distributed over a Petri dish. All Petri dishes were incubated for $24 \mathrm{~h}$ at $37^{\circ} \mathrm{C}$. Finally, the formed bacteria colonies were counted. Antibacterial activity was reported as a percent reduction of the bacteria cells after contact with treated samples compared to the number of bacteria cells remaining after being in contact with the untreated fabric. The percentage reduction $(R \%)$ was determined based on the following equation:

$$
R \%=\frac{B-A}{B} \times 100
$$

where $A$ and $B$ are the bacteria cells expressed in CFU $/ \mathrm{mL}$ for the suspension in contact with treated and control polyamide fabrics, respectively.

\section{Results and Discussion}

\subsection{Total Phenolic and Flavonoid Contents}

Table 1 shows the concentrations of the phenolic and flavonoid compounds of the pomegranate peel extract. The results evidenced that the extract possessed phenolic and flavonoid components. The brown color of the extract is chemically related to these compounds. The extract is rich in phenolics, while the flavonoids constitute a small part of the total phenolic compounds $(10 \%)$. This finding agrees with previous studies that have proven that pomegranate peels polyphenols essentially consist of tannins.

Table 1. Total phenolic compounds and flavonoids of pomegranate peels extract.

\begin{tabular}{cc}
\hline Total Phenolics & Flavonoids \\
\hline $176 \pm 11 \mathrm{mg} \mathrm{GAE} / \mathrm{g}$ & $18 \pm 3 \mathrm{mg} \mathrm{CE} / \mathrm{g}$ \\
\hline
\end{tabular}

\subsection{Visible Spectroscopy Characterization}

Figure 1 shows the visible spectrum of pomegranate peel extract. Two maxima absorptions were detected at $325 \mathrm{~nm}$ and $367 \mathrm{~nm}$. These peaks appear due to the presence of flavonoids.

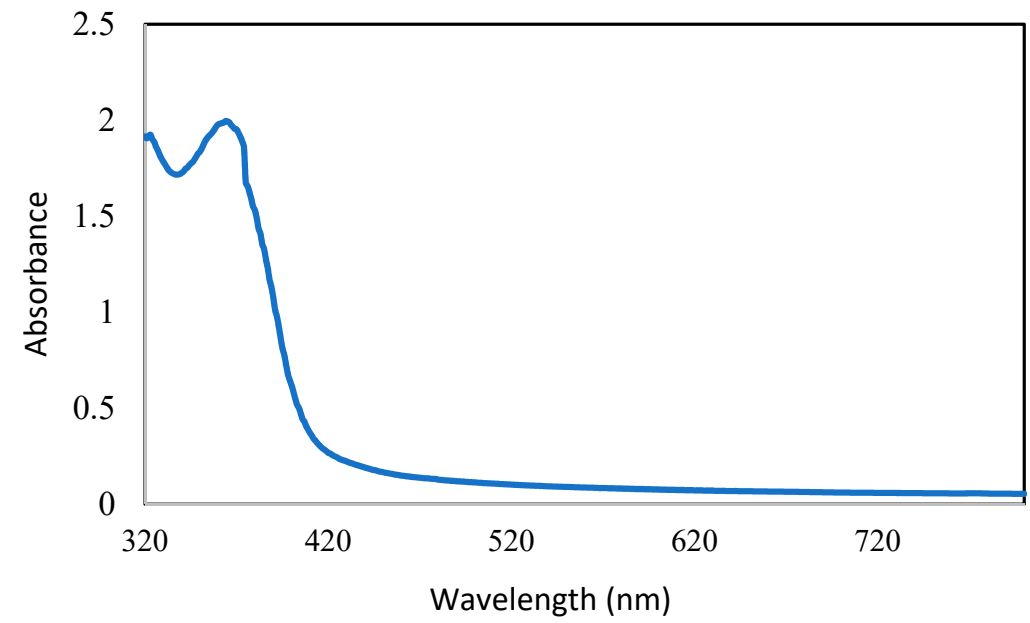

Figure 1. Visible spectrum of pomegranate peel extract. 
Generally, the visible spectrum of flavonoids shows peaks in the $300-400 \mathrm{~nm}$ region. These peaks are associated with the cinnamoyl system (Figure 2) [19]. The absorbance shifts towards higher wavelengths by increasing conjugation [20].<smiles>O=c1ccoc(-c2ccccc2)c1</smiles>

Figure 2. Structural base of the cinnamoyl system.

\subsection{Effect of the Dye Concentration}

Colorimetric data were considered to evaluate the influence of dye concentration during the dyeing of polyamide fabrics. Different dye concentrations $(2 \%, 4 \%, 5 \%, 6 \%$ and $7 \%$ ) were used. Colorimetric data are shown in Table 2.

Table 2. Shades and colorimetric data obtained for the dyed polyamide fabrics at different concentrations.

\begin{tabular}{|c|c|c|c|c|c|}
\hline Extract (\%) & Shade & $\mathrm{K} / \mathrm{S}$ & L & a & $\mathbf{b}$ \\
\hline $2 \%$ & & 2.99 & 74.92 & 3.14 & 26.81 \\
\hline $4 \%$ & & 3 & 75.34 & 3.47 & 27.49 \\
\hline $5 \%$ & & 3.06 & 75.2 & 3.71 & 30.27 \\
\hline $6 \%$ & & 3.99 & 72.57 & 4.27 & 30.35 \\
\hline $7 \%$ & & 4.31 & 71.57 & 3.90 & 28.12 \\
\hline
\end{tabular}

(Temperature: $100^{\circ} \mathrm{C}$ ).

The exploitation of the different values provides evidence that the increase in the dye concentration increases the shade intensity of dyed fabrics expressed by the color yield $(\mathrm{K} / \mathrm{S})$ values. The best value of $(\mathrm{K} / \mathrm{S})$ was obtained for a concentration of $7 \%$. The colorimetric parameters $\mathrm{L}, \mathrm{a}$ and $\mathrm{b}$ values are variable. The pomegranate peel extract gave yellow to brown shades.

The dye uptake on the polyamide fabric is primarily due to the electrostatic forces (Figure 3) created between the positively charged end amino groups of polyamide fibers and the dye molecules under acidic conditions [21]. At $\mathrm{pH}=3$, the protonation of amino groups is increased, and electrostatic interactions are enhanced. In addition to electrostatic interactions, hydrogen bonds occur between flavonoids and polyamide fibers (Figure 3). Moreover, hydrophobic interactions exist and Van der Waals attraction between the methylene groups of fibers and the aromatic moieties of flavonoids [22,23]. 


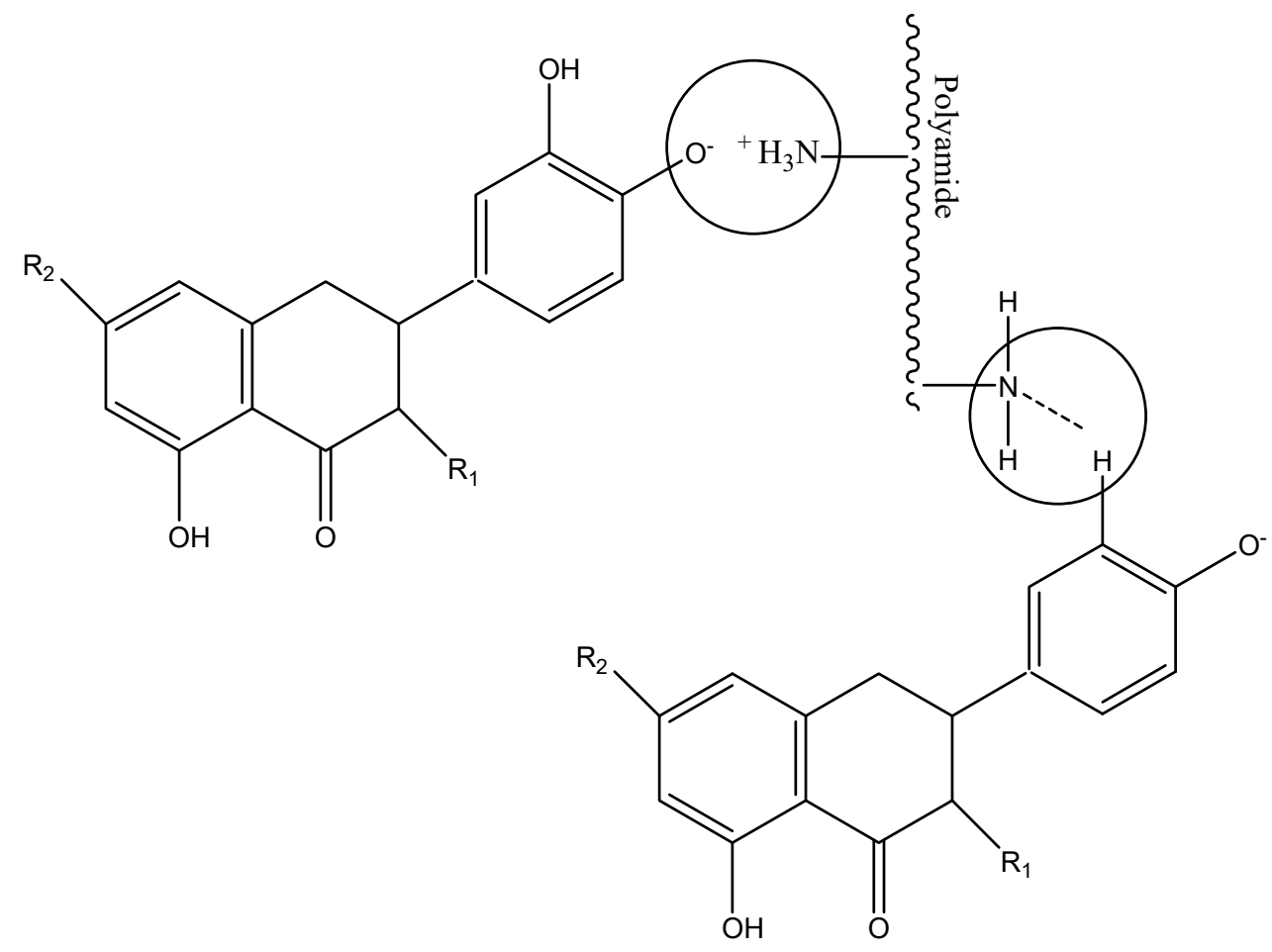

Figure 3. Electrostatic interactions and hydrogen bond between positively charged end amino groups of polyamide and flavonoids of the dye $(\mathrm{pH}=3)$.

\subsection{Effect of Dyeing Temperature}

Dyeing was carried out at different temperatures to test the effect of heating on the dyeing properties. The obtained results are recapitulated in Table 3. They clearly show that increasing the dye bath temperature results in an increase in the color strength value $(\mathrm{K} / \mathrm{S})$. The higher color strength value was obtained at $100{ }^{\circ} \mathrm{C}$. When the temperature exceeds the glass transition of polyamide, a good facility of penetration of dye takes place. Results show also that the luminosity, L, and the parameters, $\mathrm{a}$ and $\mathrm{b}$, are influenced by dyeing temperature.

Table 3. Shades and colorimetric data obtained for the dyed polyamide fabrics at different dyeing temperatures.

\begin{tabular}{cccccc}
\hline Temperature $\left({ }^{\circ} \mathbf{C}\right)$ & Shade & K/S & L & a & b \\
\hline 40 & & 1.08 & 84.50 & 1.25 & 22.14 \\
60 & 1.73 & 79.42 & 4.75 & 25.24 \\
80 & 3.46 & 70.96 & 5.33 & 28.63 \\
100 & 3.99 & 72.57 & 4.27 & 30.35 \\
\hline
\end{tabular}

(Extract: 6\%).

\subsection{Mordanting Effect}

During this work, simultaneous mordanting was used to dye polyamide fabrics with pomegranate peel extract. The mordants used were aluminum sulfate, iron sulfate, potassium dichromate and gallnut extract. Table 4 shows the influence of mordanting treatment on dyed samples in terms of their color shade and their colorimetric data. The difference in shades of the dyed fabrics can be noticed. This result can be attributed to the 
mordants effect. The use of iron sulfate and potassium dichromate has affected the shades of dyed fabrics. On the contrary, the use of aluminum sulfate and gallnut gives shades similar to that obtained without a mordant. In addition, the use of iron sulfate gave the highest $\mathrm{K} / \mathrm{S}$ value.

Table 4. Shades and colorimetric data obtained for polyamide fabrics.

\begin{tabular}{|c|c|c|c|c|c|}
\hline Mordant & Shade & K/S & $\mathbf{L}$ & $\mathbf{a}$ & B \\
\hline Without mordant & & 2.99 & 74.92 & 3.14 & 26.81 \\
\hline Iron sulfate & & 3.27 & 53.99 & 2.52 & 9.04 \\
\hline Aluminum sulfate & & 2.07 & 72.93 & 7.52 & 24.47 \\
\hline Potassium dichromate & & 2.44 & 69.65 & 6.49 & 24.81 \\
\hline Gallnut & & 2.62 & 73.45 & 3.81 & 27.63 \\
\hline
\end{tabular}

(Extract: $2 \%$, temperature: $100^{\circ} \mathrm{C}$ ).

Metal mordants are known to bind with the natural dye by forming coordination complexes. The formed complex, via mordant metal, acts as a binding agent by attracting the fiber from one side and the natural dye from the other side.

\subsection{Color Fastness}

Table 5 shows the ratings of mordanted and un-mordanted dyed polyamide fabrics for washing, rubbing and light fastness. The rubbing fastness of the un-mordanted sample was found to be quite good. However, the washing fastness was also good, but the light fastness was poor.

Table 5. Fastness results.

\begin{tabular}{ccccc}
\hline Sample & Washing & Dry Rubbing & Wet Rubbing & Light \\
\hline Without mordant & 3 & 4 & 4 & 2 \\
Iron sulfate & 4 & $4-5$ & $4-5$ & 3 \\
Aluminum Sulfate & $3-4$ & $4-5$ & $4-5$ & $2-3$ \\
Potassium dichromate & $3-4$ & $4-5$ & $4-5$ & $2-3$ \\
Gallnut & $3-4$ & $4-5$ & $4-5$ & $2-3$ \\
\hline
\end{tabular}

Natural dyes have long been known to have low light fastness. Using mordants, the wash fastness of mordanted samples was found to improve from a rating of three to a rating of four. These findings suggest that mordants are able to improve the wash fastness ratings of polyamide fabrics. Iron sulfate was the best mordant to improve light fastness.

\subsection{Antibacterial Testing}

Figure 4 shows the results of ASTM E2149 antibacterial testing against two strains: E. coli and S. aureus, after $1 \mathrm{~h}$ of contact. Results of testing against S. aureus, which is Gram positive, show low reduction rates. The finishing with natural dye does not significantly reduce the bacteria concentration. The best result was obtained for the dyed fabric after mordanting using iron sulfate with a reduction rate of $67 \%$. By contrast, the efficacy against E. Coli shows better results, with reduction rates up to $91 \%$. The differing efficacy responses may be related to the different Gram statuses. The antibacterial activity of dyed polyamide fabrics was ranked as iron sulfate $>$ aluminum sulfate $>$ potassium dichromate $>$ gallnut $>$ 
un-mordant against S. aureus and E. coli. The use of mordants enhances antibacterial activity. It is well known that metallic salts exhibit toxic effects against microorganisms.

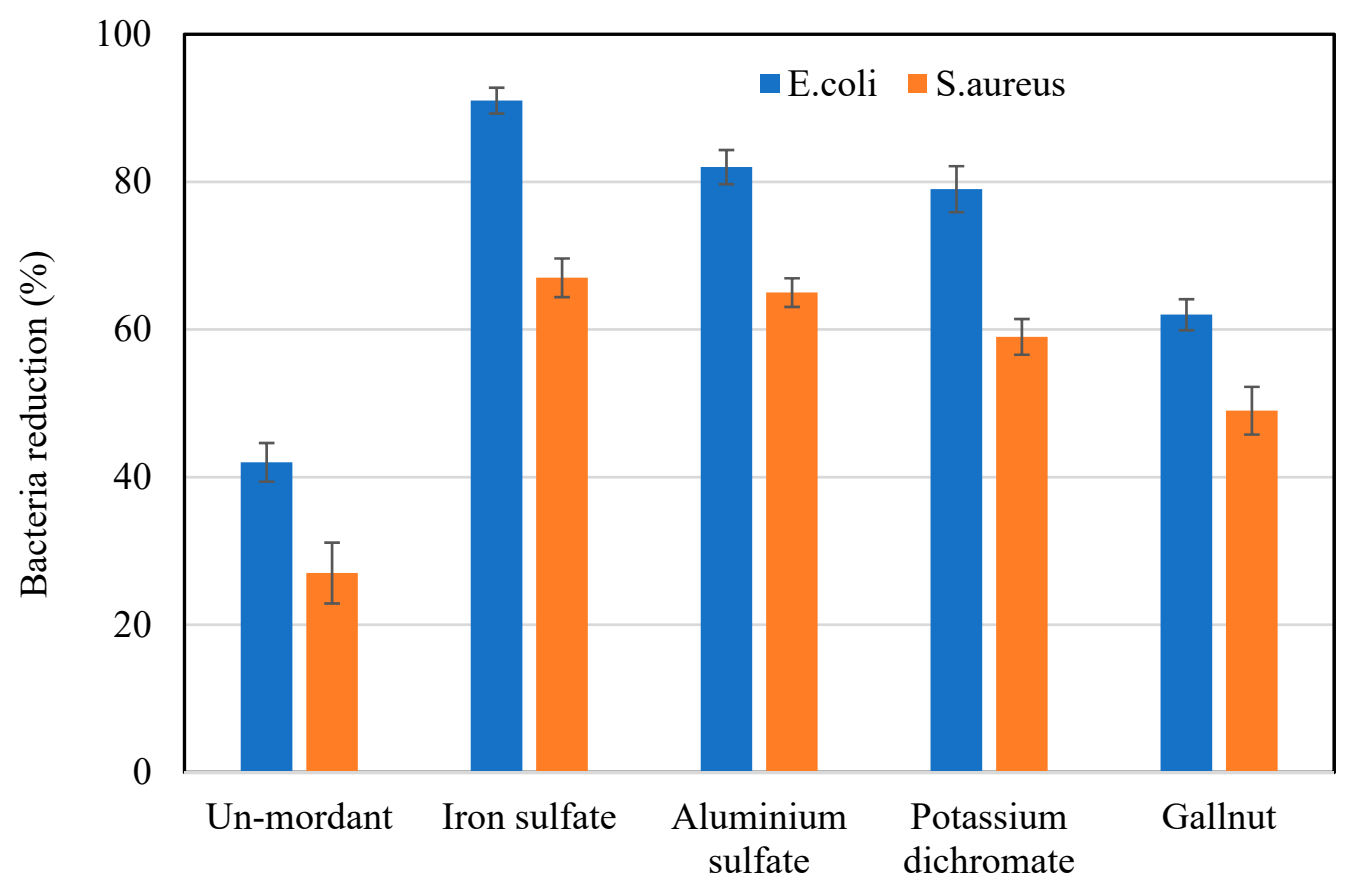

Figure 4. The antibacterial rates of dyed polyamide fabrics against bacteria strains.

\section{Conclusions}

The aim of this work was to use pomegranate by-products as natural dye for an environmentally friendly and sustainable textile dyeing process. During the polyamide dyeing process, yellow and brown hues were obtained. The effects of dye concentration and temperature on polyamide dyeability were evaluated, and it was discovered that the concentration and temperature had a significant impact on the colors obtained. High concentrations at $100{ }^{\circ} \mathrm{C}$ produced the best results. The rates of washing and rubbing fastness were good to excellent, and the rates of light fastness were fair to good. When mordants are used with extracts, the dyeability and fastness properties are improved. The antibacterial testing of the treated polyamide fabrics led to encouraging results. Further investigations are, however, needed to evaluate the durability of their antibacterial activity after washing and exposure to light.

Author Contributions: Conceptualization, A.B., D.D. and S.G.; methodology, A.B., D.D., S.C. and S.G.; experiments, A.B., D.D., S.G., S.A. and S.C.; validation, C.B., A.K. and S.A.; analysis, A.B., D.D., S.G. and S.A.; investigation, A.B., D.D. and S.G.; resources, C.B. and S.G.; writing-original draft preparation, A.B., D.D. and S.G.; writing—review and editing A.B., D.D., S.G., A.K. and S.A.; supervision, C.B., S.A., A.K. and S.C.; project administration, S.G. and C.B. All authors have read and agreed to the published version of the manuscript.

Funding: This research received no external funding.

Institutional Review Board Statement: Not applicable.

Informed Consent Statement: Not applicable.

Data Availability Statement: Data sharing is not applicable to this article.

Conflicts of Interest: The authors declare no conflict of interest. 


\section{References}

1. Schieber, A.; Stintzing, F.C.; Carle, R. By-products of plant food processing as a source of functional compounds-Recent developments. Trends Food Sci. Technol. 2001, 12, 401-413. [CrossRef]

2. Sagar, N.A.; Pareek, S.; Sharma, S.; Yahia, E.M.; Lobo, M.G. Fruit and vegetable waste: Bioactive compounds, their extraction, and possible utilization. Compr. Rev. Food Sci. Food Saf. 2018, 17, 512-531. [CrossRef] [PubMed]

3. Trigo, J.P.; Alexandre, E.M.; Saraiva, J.A.; Pintado, M.E. High value-added compounds from fruit and vegetable by-productsCharacterization, bioactivities, and application in the development of novel food products. Crit. Rev. Food Sci. Nutr. 2020, 60, 1388-1416. [CrossRef] [PubMed]

4. Đilas, S.; Čanadanović-Brunet, J.; Ćetković, G. By-products of fruits processing as a source of phytochemicals. Chem. Ind. Chem. Eng. Q. CICEQ 2009, 15, 191-202. [CrossRef]

5. Yahia, E.M.; García-Solís, P.; Celis, M.E.M. Contribution of fruits and vegetables to human nutrition and health. In Postharvest Physiology and Biochemistry of Fruits and Vegetables; Elsevier: Amsterdam, The Netherlands, 2019; pp. 19-45.

6. Haddar, W.; Baaka, N.; Meksi, N.; Ticha, M.B.; Guesmi, A.; Mhenni, M.F. Use of ultrasonic energy for enhancing the dyeing performances of polyamide fibers with olive vegetable water. Fibers Polym. 2015, 16, 1506-1511. [CrossRef]

7. Meksi, N.; Haddar, W.; Hammami, S.; Mhenni, M. Olive mill wastewater: A potential source of natural dyes for textile dyeing Ind. Crop. Prod. 2012, 40, 103-109. [CrossRef]

8. Guesmi, A.; Dhahri, H.; Hamadi, N.B. A new approach for studying the dyeability of a multifibers fabric with date pits powders: A specific interest to proteinic fibers. J. Clean. Prod. 2016, 133, 1-4. [CrossRef]

9. Dos-Santos, M.J.P.L. Value Addition of Agricultural Production to Meet the Sustainable Development Goals. In Zero Hunger Encycopedia of the UN Sustainable Development Goals; Leal Filho, W., Azul, A.M., Brandli, L., Özuyar, P.G., Wall, T., Eds.; Springer International Publishing: Cham, Switzerland, 2020; pp. 1-8.

10. Gong, K.; Rather, L.J.; Zhou, Q.; Wang, W.; Li, Q. Natural dyeing of merino wool fibers with Cinnamomum camphora leaves extract with mordants of biological origin: A greener approach of textile coloration. J. Text. Inst. 2020, 111, 1038-1046. [CrossRef]

11. Peran, J.; Ercegović Ražić, S.; Sutlović, A.; Ivanković, T.; Glogar, M.I. Oxygen plasma pretreatment improves dyeing and antimicrobial properties of wool fabric dyed with natural extract from pomegranate peel. Coloration Technol. 2020, 136, 177-187. [CrossRef]

12. Çam, M.; Hışıl, Y.; Durmaz, G. Classification of eight pomegranate juices based on antioxidant capacity measured by four methods. Food Chem. 2009, 112, 721-726. [CrossRef]

13. Ozgen, M.; Durgaç, C.; Serçe, S.; Kaya, C. Chemical and antioxidant properties of pomegranate cultivars grown in the Mediterranean region of Turkey. Food Chem. 2008, 111, 703-706. [CrossRef]

14. Sreekumar, S.; Sithul, H.; Muraleedharan, P.; Azeez, J.M.; Sreeharshan, S. Pomegranate fruit as a rich source of biologically active compounds. BioMed Res. Int. 2014, 2014. [CrossRef] [PubMed]

15. Dif, M.; Benchiha, H.; Mehdadi, Z.; Benali-Toumi, F.; Benyahia, M.; Bouterfas, K. Étude quantitative des polyphénols dans les différents organes de l'espèce Papaver rhoeas L. Phytothérapie 2015, 13, 314-319. [CrossRef]

16. Zhishen, J.; Mengcheng, T.; Jianming, W. The determination of flavonoid contents in mulberry and their scavenging effects on superoxide radicals. Food Chem. 1999, 64, 555-559. [CrossRef]

17. Menezes, E.; Carapelli, R.; Bianchi, S.; Souza, S.; Matos, W.; Pereira-Filho, E.; Nogueira, A. Evaluation of the mineral profile of textile materials using inductively coupled plasma optical emission spectrometry and chemometrics. J. Hazard. Mater. 2010, 182, 325-330. [CrossRef]

18. Iva Rezić, I.S. ICP-OES determination of metals present in textile materials. Microchem. J. 2007, 85, 46-51. [CrossRef]

19. Mabry, T.; Markhan, K.; Thomas, M. The Systemic Identification of Flavonoids; Springer: New York, NY, USA, 1970 ; pp. 46-54.

20. Halbwirth, H. The creation and physiological relevance of divergent hydroxylation patterns in the flavonoid pathway. Int. J. Mol. Sci. 2010, 11, 595-621. [CrossRef]

21. Lokhande, H.; Dorugade, V.A. Dyeing nylon with natural dyes. Am. Dyest. Report. 1999, 88, $29-34$.

22. Li, Y.-D.; Guan, J.-P.; Tang, R.-C.; Qiao, Y.-F. Application of natural flavonoids to impart antioxidant and antibacterial activities to polyamide fiber for health care applications. Antioxidants 2019, 8, 301. [CrossRef] [PubMed]

23. Tang, R.-C.; Tang, H.; Yang, C. Adsorption isotherms and mordant dyeing properties of tea polyphenols on wool, silk, and nylon. Ind. Eng. Chem. Res. 2010, 49, 8894-8901. [CrossRef] 